\title{
A NEW APPROACH FOR DETERMINING THE MOST IMPORTANT SYSTEM COMPONENTS AND THE BUDGET-CONSTRAINED SYSTEM RELIABILITY IMPROVEMENT
}

\section{NOWE PODEJŚCIE DO WYZNACZANIA NAJWAŻNIEJSZYCH ELEMENTÓW SYSTEMU ORAZ POPRAWY NIEZAWODNOŚCI SYSTEMU W WARUNKACH OGRANICZONEGO BUDŻETU}

\begin{abstract}
Importance measures are used for indexing system components due to their impact on the system 's overall reliability. In order to identify the specific number of the most critical components, first-ranked components are singled out as the most important ones. However, importance measures consider only the influence of individual components and they are not applicable to combinations or groups of components. This common feature of importance measures is referred to in literature as one of still open issues. This paper proposes a new approach for determining the most important system components, where a whole set of components are determined simultaneously taking into account their interdependence. In systems with a large number of interdependent components, the number of the most important components which should be prevented is often limited due to the available budget. Using pre-known minimal cut sets, a mathematical model based on the Budgeted Maximum Coverage Problem is proposed. By its optimization, the simultaneous determination of all of the most important components whose total expenses do not exceed the limited overall budget is achieved. The new approach was tested by a series of experiments conducted over a set of test examples. The results of the experiments were compared with the results obtained using two commonly used cost importance measures.
\end{abstract}

Keywords: reliability, importance measures, critical components, budgeted maximum coverage problem, optimization.

\begin{abstract}
$W$ zlożonych systemach, w których koszty poprawy niezawodności poszczególnych elementów sq znane, często ogranicza się budżet przeznaczony na podnoszenie ogólnej niezawodności systemu. W takich przypadkach konieczna jest maksymalizacja niezawodności systemu przy jednoczesnym utrzymaniu kosztów na poziomie minimum. Powszechnie znane metody rozwiazywania powyższego problemu opierają się na wyznaczaniu ważności kosztów, co wymaga określenia rang elementów skladowych systemu, a w dalszej kolejności wyodrębnienia pewnej liczby najważniejszych elementów pierwszorzędnej rangi. W niniejszej pracy zaproponowano nowe podejście do określania najważniejszych komponentów systemu w oparciu o problem maksymalnego pokrycia w granicach budżetu (budgeted maximum coverage problem); podejście wdrażano z wykorzystaniem wcześniej znanych minimalnych przekrojów niezdatności. Optymalizacja proponowanego modelu matematycznego, pozwolita na jednoczesne wyznaczenie wszystkich najważniejszych elementów, dla których łączne wydatki na utrzymanie ruchu nie przekraczały całkowitego ograniczonego budżetu. Nowe podejście zostało przebadane w serii eksperymentów przeprowadzonych na zbiorze przykładów testowych, za które postużyty wzorcowe drzewa błędów. Wyniki badań porównano z wynikami uzyskanymi za pomoca dwóch miar ważności kosztów - miary ważności opartej na kosztach oraz miary ważności opartej na opłacalności. W większości przypadków, proponowany model dawał lepsze wyniki niż pomiary ważności kosztów.
\end{abstract}

Stowa kluczowe: niezawodność, miara ważności, elementy krytyczne, problem maksymalnego pokrycia zbioru w granicach budżetu, optymalizacja.

\section{Introduction}

Improvement of the reliability of a complex system, besides providing redundancy of components, is achieved by improving the reliability of the individual components that have the greatest impact on the overall reliability of the system. In this paper, we consider a complex system as a system with multiple interactions between many different components [15] in which the behavior of the system cannot be easily and directly induced from the behavior of its components [3]. Within the context of reliability, main characteristics of a complex system are: large number of components, cut sets, path sets or components' states dependencies [7]. Analysis of the impact of the com- ponents' reliability on the overall system reliability is usually done by using importance measures. The concept of importance measures, originally introduced by Birnbaum [2] and Vesely [23], has been significantly changed and improved over time. Structural and probabilistic importance measures are used most often, but a small number of importance measures that take into account the costs of improving the reliability of the individual components have also been developed over the last few years $[12,24]$. A common feature of the majority of importance measures is that component's importance to the system functioning and failure is determined based on the calculated value of a chosen importance measure [27]. Therefore, the general procedure 
of their application is: firstly, the numerical value for the importance of each individual component is calculated using the chosen importance measure formulae; secondly, components are ranked considering previously calculated values. In the case a desired number $k$ of the most important components need to be determined, it would be the $k$ first-ranked components since the higher ranked components are considered the most critical. There are some importance measures available in the literature that do not fully share the mentioned common feature. Joint Reliability Importance (JRI) analyses a pair of components [1], Differential Importance Measure (DIM) is calculated as a sum of the individual importance measures [4], and enxtention of DIM called DIM ${ }^{\mathrm{II}}$ combines JRI and DMI [29]. However, according to Zio [28], the fact that the majority importance measures rank only individual components so that they are not directly applicable to combinations or groups of components, is still one of the open issues on importance measures.

The subject of this paper is the formulation and validation of a new importance measure which, unlike the existing approaches, besides considering costs of individual components takes into account their mutual impact on the overall system reliability. The new measure is formulated as an optimization problem, more precisely as the Budgeted Maximum Coverage Problem (BMCP). BMCP is presented by Khuller as the variation of Maximum Coverage Problem [13], but in literature, it is also recognized as a Maximum Coverage with Knapsack Constraints [8]. The approach found its application in graphs $[5,21]$, location problems [19] and healthcare networks monitoring [6]. This paper could indicate the first usage of BMCP in reliability since the authors of this paper have not been able to find any previous applications in this area. There are examples in the literature where information provided by importance measures is used in the formulation of an optimization problem in order to obtain a system design in which all components have similar importance values [30]. However, according to our knowledge, optimization approach so far has not been used to determine the importance of the components. Using the new proposed optimization approach all of the most critical components are determined simultaneously, and the sum of their individual costs fits the available budget. The approach is experimentally tested and the obtained results verifying the approach are presented and explained.

The proposed approach is based upon minimal cut sets (MCSs) of coherent fault trees, so the terminology of the fault tree analysis is used. Primary events, which represent the system components' failures, are elements of MCSs. Cut sets and MCSs are defined as follows:

Definition 1 [9]: Cut set is a set of events that together cause the top undesired event to occur.

Definition 2 [9]: Minimal cut set (MCS) is a cut set reduced to a minimum number of events that cause the top undesired event to occur.

MCSs are most commonly generated based on a fault tree of the observed system [16]. Formally, a fault tree is a directed and connected acyclic graph $\mathrm{G}=(\mathrm{N}, \mathrm{A})$, where $\mathrm{N}$ is the set of nodes and $\mathrm{A}$ is the set of arcs (Fig. 1).

The top event of the fault tree (root node TE), represents a system failure. The failure modes of the system components are primary events (components' failures) represented by leaves e1-e6. Besides intermediate nodes G1-G4, a given fault tree has four logic operators that model the cause-effect relationships between components' failures - two OR operators are assigned to G1 and G2 while two AND operators are assigned to nodes G3 and G4. For the fault tree shown in Figure 1, MCSs are: e1e4, e1e5e6, e2e3e4 and e2e3e5e6. Each of these combinations of primary events could cause the system failure. The qualitative analysis (in the process of Boolean reduction of a set of equations) identifies the minimal cut sets which are the combinations of the smallest number of primary events and if they

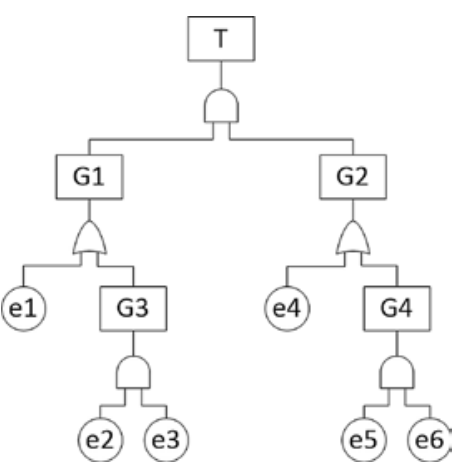

Fig. 1. Fault tree example

occur simultaneously, they may lead to a top event. The top event can be expressed as [26]

$$
T E=\bigcup_{i=1}^{n} M C S_{i}=\bigcup_{i=1}^{n}\left(\bigcap_{j=1}^{m} P_{j}\right)_{i}
$$

where $T E$ is the top event, $M C S_{i}$ is the $i$-th minimal cut set, $n$ is the total number of minimal cut sets, $P_{j}$ is the $j$-th primary event and $m$ is the total number of primary events. The quantitative analysis represents a calculation of the top event probability. Considering the assumption that the primary events are mutually independent, the top event probability of occurrence $Q_{T E}$ may be approximated as [26]

$$
Q_{T E}=\sum_{i=1}^{n} Q_{M C S_{i}}=\sum_{i=1}^{n}\left(\prod_{j=1}^{m} Q_{P_{j}}\right)_{i}
$$

where $Q_{M C S_{i}}$ is the probability of occurrence of the minimal cut set $i$ and $Q_{P_{j}}$ is the probability of occurrence of the primary event $j$. The proposed approach assumes that all MCSs of a given fault tree are already determined.

The paper is organized as follows: Section 2 deals with importance measures that consider the cost of components used for the validation of a proposed approach. The problem of simultaneous determination of the most critical system components constrained with alimited budget is formulated as BMCP in Section 3. A mathematical model of a formulated optimization problem and solving methods are presented in Section 4. Section 5 gives the comparison of the results obtained by the proposed model with the results obtained using the importance measures from Section 2, tested on a group of benchmark fault trees. Concluding remarks and discussion are presented in Section 6.

\section{Importance measures that consider costs of compo- nents}

The importance measures indicate the system components that have the greatest impact on the reliability of the system [10]. Overviews of some of the most used importance measures are available in many books and papers [14, 20, 22].

The two importance measures used in this paper to compare results with our proposed approach are Cost-based component importance $(\mathrm{CBCI})$ and Cost-effective importance measure (CEIM).

$\mathrm{CBCI}$ is introduced as the extension of Birnbaum importance [25]. In our paper CBCI of component $i$ is defined as:

$$
I_{i}^{C B C I}(t)=-\frac{\partial C_{i}(t)}{\partial R_{i}}
$$


where $\partial C_{i}(t)$ and $\partial R_{i}$ represent the increase of system cost and system reliability caused by reliability improvement of $\mathrm{i}$-th component, respectively. $\mathrm{CBCI}$ can be interpreted as follows: when $I_{i}^{C B C I}(t)$ is large, a small change in the reliability of component $i$ will result in a comparatively large change in the total cost of maintaining the entire system during the time interval $(0, t)$.

CEIM combines the concept of reliability importance measure and the total costs of failure, and it is defined as:

$$
I_{i}^{C E I M}(t)=\frac{I_{i}^{G I}(t)}{C_{f, i}}
$$

where $I_{i}^{G I}$ is the general importance (GI) of component $i$ at time $t$, and $C_{f, i}$ is a cost factor for $i$-th component. GI of component $i$ is calculated as:

$$
I_{i}^{G I}(t)=\frac{\Delta g_{i}(Q(t))}{g(Q(t))}
$$

where $\Delta g_{i}(Q(t))$ represents the change in system probability due to change in $\mathrm{i}$-th component probability. The cost factor for $i$-th component is calculated as the ratio of sum of the expected costs of failure for all components and the expected cost of reliability improvement for $i$-th component:

$$
\Delta g_{i}(Q(t))
$$

where $E\left(C_{i}\right)$ is the expected cost of reliability improvement for $i$-th component. A component which gives a maximum benefit at minimum costs will be termed as the most cost-effective component and will possess the highest rank in priority list [12].

\section{Problem formulation}

In this paper, we observe the improvement of components reliability as a decrease of component's failure probability to a very low or negligible value, close to zero. This assumption appears in most importance measures and represents a decreased risk level with the component optimized or assumed to be perfectly reliable, i.e. components reliability equal to 1 [20].

If we observe the fault tree given at Figure 1, we can assign costs for their six primary components, for example: $\mathrm{c} 1=5, \mathrm{c} 2=6, \mathrm{c} 3=7$, $\mathrm{c} 4=8, \mathrm{c} 5=7$ and $\mathrm{c} 6=6$ cost units (c.u.). Also we can assume some limited budget, for example $\mathrm{B}=15$ c.u., available for improvement of the most critical system components. In that case, both CBCI and CEIM can be calculated using equations (3) and (4) in order to find which components should be improved. After calculation of values for each component, we are able to make rankings presented in the table below:

Both measures basically gave the same output. They selected components e1 and e4 as the most critical, and their total costs of improvement of 13 c.u. fit the available budget. If we calculate the

Table 1. Rankings of components' importance using CBCI and CEIM

\begin{tabular}{|c|c|c|c|c||}
\hline Rank & $\begin{array}{c}\text { Component } \\
\text { ranking by CBCI }\end{array}$ & $\begin{array}{c}\text { Calculated } \\
\text { CBCI value }\end{array}$ & $\begin{array}{c}\text { Component } \\
\text { ranking by CEIM }\end{array}$ & $\begin{array}{c}\text { Calculated } \\
\text { CEIM value }\end{array}$ \\
\hline 1. & e1 & 40.58 & e4 & 0.19 \\
\hline 2. & e4 & 64.94 & e1 & 0.12 \\
\hline 3. & e6 & 175.93 & e3 & 0.02 \\
\hline 4. & e2 & 175.93 & e5 & 0.02 \\
\hline 5. & e3 & 205.28 & e2 & 0.01 \\
\hline 6. & e5 & 205.28 & e6 & 0.01 \\
\hline
\end{tabular}

overall system reliability improvement, we get apercentage of 99.17 , which is a good result. This improvement is obtained by comparing the initial system reliability with the reliability of the system in which selected components (e1 and e4) are assumed to be perfectly reliable.

Observing the list of MCSs from the example given in figure 1, it can be seen that primary events e1 and e 2 are present in every MCS. Therefore, if those two components were selected for improvement of their reliability i.e. the probability of their failure is set to zero, then regarding equation (2) the probability of occurrence of TE would also equal zero. Thus, by selecting components e1 and e 2 the percentage of $100 \%$ of system reliability improvement can be achieved. Components e 1 and e 2 fits limited budget even better, as their total costs are only 11 c.u.

In addition, if the available budget is increased, the results of $\mathrm{CBCI}$ and CEIM could be used just to add next lower ranked component to the set of the previously selected most critical components with a higher ranking. The approach proposed in this paper in case of increasing the available budget is able to find completely different set $\mathrm{K}$ of $k$ critical components which achieve higher overall system reliability improvement, while still fitting the budget. The traditional way of calculating importance measures by making independent calculations for each individual component and linear expansion of set $\mathrm{K}$ of $k$ critical components in case the available budget is increased, are issues that are overcome by the approach proposed in this paper.

The new approach of determining the most important system components relies on minimal cut sets defined in the introduction chapter. The basic implication of definitions 1 and 2 is - if any of components/ events which are the element of an MCS can be prevented to fail, then MCS stops to be the cause of possible system failure and is considered eliminated or "covered". The probability of realization of MCS is then used to diminish the overall system failure probability, i.e. system reliability is improved at the same rates. The goal is to select components which should be improved so that their non-failure would maximize the reduction of the overall system failure probability.

Starting presumptions are:

- Minimal cut sets of the observed system are known

- Probabilities for failure of systems' components are given (or their order of magnitude)

- Cost of improvement is known for each individual component

- Total budget available for system reliability improvement is given and limited

The proposed approach can be formulated as an optimization problem described as follows: allocate the available budget to ensure non-failure of components which eliminate the most probable MCSs i.e. which maximize the reduction of the system failure probability.

\section{Mathematical model and solving methods}

Mathematical model of described optimization problem is made using the following notation:

$-S$ - set of primary events;

- $i \in S$ - primary event which represents the failure of $i$-th system component;

- $m$ - the number of MCSs;

$-w_{j}$ - weight, i.e. probability for the realization of $j$-th minimal cut set (calculated by multiplying failure probabilities of its components)

$-c_{i}-$ cost for preventing $i$-th component from failure, i.e. improving it for non-failure

- B - available budget for system reliability improvement

- $a_{i j}$ - binary variable defined as:

$a_{i j}=\left\{\begin{array}{l}1, \text { if } i \text {-th component is an element of } j \text {-th minimal cut-set } \\ 0, \text { othervise }\end{array}\right.$ 
$-x_{i}$ - binary variable called a disabling indicator associated with the primary event $i, i \in S$, defined as:

$x_{i}=\left\{\begin{array}{l}1, \text { if the primary event } i \text { is disabled (componetnt functioning) } \\ 0, \text { othervise (component failure) }\end{array}\right.$

- $y_{j}$ - binary variable called elimination indicator associated with the $\operatorname{MCS} j, j=1, \ldots, m$, defined as:

$$
y_{i}=\left\{\begin{array}{l}
1, \text { if } j \text {-th minimal cut-setis disabled (covered) } \\
0, \text { othervise }
\end{array}\right.
$$

The mathematical model of allocating limited budget to prevent failure of those components which eliminate the most probable minimal cut sets, is formulated as follows:

BMCP (budgeted maximum coverage model):

$$
\max f(x, y)=\sum_{j=1}^{m} w_{j} y_{j}
$$

s.t.

$$
\begin{gathered}
\sum_{i \in S} a_{i j} x_{i} \geq y_{j}, j=1, \ldots, m \\
\sum_{i \in S} C_{i} x_{i} \leq B \\
x_{i} \in\{0,1\}, i \in S \\
y_{j} \in\{0,1\}, j=1, \ldots, m
\end{gathered}
$$

Objective function maximizes the overall probability of eliminated MCSs which implicate the increase of system reliability. The first constraint ensures elimination of all of the MCSs which contain any failure prevented components. The second constraint is related to the available budget. Considering the first constraint and the maximization of the objective function, the binary requirement for avariable can be relaxed with . The formulated mathematical model corresponds to the Budgeted Maximum Coverage Problem [13] as well as a Maximum Coverage with Knapsack Constraints [8].

Mathematical model BMCP was solved in two ways. Firstly, it was solved exactly using GLPK solver [11], and then the possibility of failure equal to zero was assigned to all selected events that should be prevented; using equation (2) a new system reliability and the percentage of reliability improvement is calculated. Secondly, it was solved using a heuristic developed for the observed problem, called GreedyPlus. The proposed heuristic uses a variation of the greedy algorithm, slightly improved to be able to recognize and remove components which cover redundant MCSs. Thus the overall system reliability could be improved by selecting some new components whose failures should be prevented. For each event, weights of all MCSs that contain specific event are summarized and based on that, events are sorted in a non- decreasing array. Events are selected, starting from the first one of that series until the budget is exhausted. Algorithm also picks the cheapest components in the case of a tie. After each selection of event, all MCSs containing the selected event are eliminated, i.e. set to 0 , and the remaining events after each step form a new array based on the weights of the remaining uncovered MCSs. Adaptation of greedy algorithm is reflected in the fact that the reduction procedure after each step has to check whether any of the already selected events is unnecessary, i.e. whether it covers exactly the same MCSs as some of the already selected events. In this case, the solution is reduced, i.e. such an event is discarded. The budget is increased for the amount of cost of discarded event so a new event needs to be selected. Since the BMCP is NP-hard [13], it can be difficult to find its optimal solution for large fault treesin areasonable time. For this purpose, GreedyPlus could be used as the starting point for future development of some special heuristics that would deal with the mentioned problem. Algorithm of GreedyPlus and pseudo-codes for the used procedures are given below. Notation used in algorithm description is:

$W_{i}$ - the sum of the weights of MCSs that contain $i$-th event, $i \in S$,

$L$ - non-decreasing array consisting of non-redundant calculated values $W_{i}, i \in K$.

$c_{i} \quad$ - cost for $i$-th component being prevented from failure

B - available budget for system improvement

\begin{tabular}{ll}
\hline Algorithm 1. GreedyPlus \\
\hline 1 & greedy() \\
2 & count single coverings and form array L \\
3 & reduction() \\
\hline
\end{tabular}

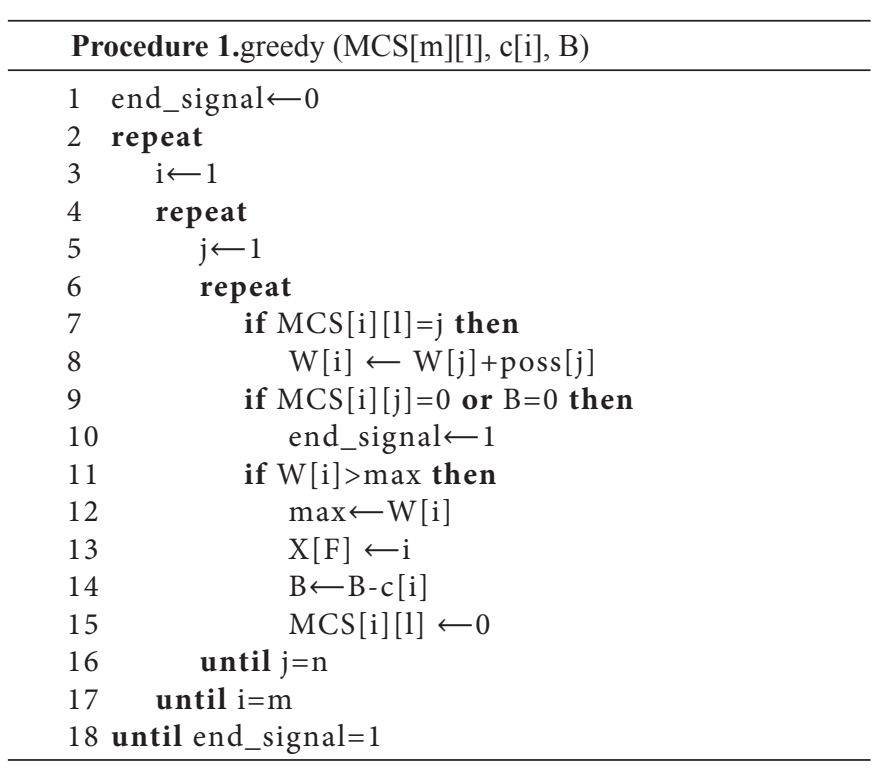

Procedure 2. reduction (X[F], Lmin, appearanceNo[F])

1 singleCover[] $\leftarrow 0$

$2 \mathrm{i} \leftarrow 1$

3 repeat

4 if $\mathrm{X}[\mathrm{i}]=$ appearanceNo[i] then

until $\mathrm{i}=\mathrm{F}$

singleCover $[\mathrm{i}] \longleftarrow$ singleCover $[\mathrm{i}]+1$

$\mathrm{i} \leftarrow 1$

repeat

if singleCover $[\mathrm{i}]=0$ then

$10 \quad$ singleCover $[\mathrm{i}] \leftarrow$ singleCover $[\mathrm{i}]+1$

$11 \quad \mathrm{~B} \leftarrow \mathrm{B}+\mathrm{c}[\mathrm{i}]$

$12 \quad \mathrm{X}[\mathrm{i}] \leftarrow \varnothing$

13 until $i=n$

$14 \operatorname{greedy}(\operatorname{MCS}[\mathrm{m}][\mathbf{1}], \mathrm{c}[\mathrm{i}], \mathrm{B})$

Both solutions of BMCP model, the optimal solution obtained by GLPK and the solution obtained using GreedyPlus, were compared with solutions obtained by CBCI and CEIM.

\section{Experimental results}

The proposed new approach is first ilustrated on the fault tree of train rear-end collision accident and then on a group of benchmark fault trees. 
The fault tree of train rear-end collision accident, retrieved from [17], consists of 35 primary and 17 intermediate events. The observed fault tree has $24000 \mathrm{MCSs}$ which means that top event called "train of primary events of $18000 \mathrm{MCSs}$ is nine while the rank of the remaining $6000 \mathrm{MCSs}$ is eight.

In order to apply the proposed approach, the following assumptions were introduced: the probabilities of all primary events are 0.01 ; the available budget for system reliability improvement is 60 cost units; and the costs for preventing components from failure are between 5 and 30 cost units. In addition, since events 1 and 2 from [17] appear in all MCSs, those two events are immediately identified as the most important and further analysis was made for the remaining 33 events.

Presented mathematical model (7-9) was first solved exactly using GLPK solver [10] and the percentage of reliability improvement is calculated according to the optimal solution. Then, reliability improvement percenteges obtained by CBCI and CEIM importance measures are calculated in the following steps:

step 1: Using equations (3) and (4), different ranks of primary events were obtained.

step 2: The possibility of failure eaqual to zero was assigned to the top ranked primary events whose total costs do not exceed the available budget.

step 3: A new system reliability was calculated.

step 4: Percentages of improvement of the system relialibility were calculated.

Optimization using GLPK and steps 1 to 4 were repeated for ten instances of randomly generated costs for preventing components from failure. The obtained results are presented in Table 2. Notation used in Table 2 is: $\mathrm{BS}=$ budget spent (percentage), $\mathrm{NC}=$ number of components, and $\mathrm{RI}=$ reliability improvement (percentage).

The results in Table 2 show that the proposed approach outperforms both importance measures in all ten instances. In eight instances, reliability improvement of $100 \%$ is achieved which means that obtained events cover all MCSs. In the case of CEIM and CBCI, such reliability improvement is obtained only in one instance. This is directly caused by the fact that those measures calculate only individual contribution to system reliability and do not consider the impact of groups of components. On the other hand, based on the proposed approach, a set of the most important components often contains components whose individual impact is not among the best ranked. For example, in the first instance, the set of the most critical events consists of events: 7, 8, and 9, according to the optimal solution of (7-9). The rear-end collision" has 24000 failure modes. The rank, i.e. the number

event 8 is second ranked by CEIM, event 9 is sixst ranked by $\mathrm{CBCI}$, while the event 7 is not among the first ranked by any of them. However, their combination provides the highest reliability improvement. Similar observations apply for all other instances.

Mathematical model (7-9) and the proposed algorithm are afterwards verified by experiments conducted used as test examples [18]. Characteristics of those benchmark fault trees (BFT) are given in Table 3:

Table 3. Benchmark fault trees

\begin{tabular}{|ccccc||}
\hline BFT name & E & BE & MCS & R \\
\hline das9201 & 204 & 122 & 14217 & $2-7$ \\
das9202 & 85 & 49 & 27778 & $1-11$ \\
baobab2 & 72 & 32 & 4805 & $2-6$ \\
baobab3 & 187 & 80 & 24386 & $2-11$ \\
\hline
\end{tabular}

The column labeled with $\mathrm{E}$ gives the total number of events contained in fault tree, while BE column gives the number of primary events (components' failure) i.e. events that form minimal cut sets. Total number of minimal cut-sets in the fault tree is given in the column MCS. Column R gives ranges of ranks for minimal cut-sets (e g. a tree named das9201 has the smallest MCS's rank of 2, while the highest rank of MCSs in that BFT is 7, and so on).

Ten random instances of costs of improvement for primary events/ components are generated for each BFT given in Table 3. For each instance four available budgets were tested, so it was made 160 experiments in total. Each experiment gave four outputs for each of tested methods (CBCI, CEIM, GLPK and GreedyPlus). Average values of the experimental results are presented in Table 4.

Notation used in Table 4 is given bellow:

ABS = average budget spent (cost units)

$\mathrm{ANC}=$ average number of components $(\mathrm{avg}$ for 10 instances, each inst. outputed int value)

ARI = average reliability improvement (percentage)

$\mathrm{B} \quad=$ available budget (cost units)

Observing the obtained results, it can be seen that GLPK and GreedyPlus gave better, or at least the same quality outputs as CBCI and CEIM, i.e ARI value in columns labeled GLPK and GreedyPlus are generally much larger than values in CBCI and CEIM columns. Due to the way Table 2. Results of ten instances for the fault tree of train rear-end collision accident

\begin{tabular}{|c|ccc|c|c|c|c|c|c||}
\hline \multirow{2}{*}{ instances } & \multicolumn{3}{|c|}{ GLPK } & \multicolumn{3}{c|}{ CEIM } & \multicolumn{3}{c||}{ CBCI } \\
\cline { 2 - 10 } & NC & RI & BS & NC & RI & BS & NC & RI & BS \\
\hline 1 & 3 & 100 & 78.33 & 3 & 60 & 98.33 & 8 & 85.60 & 100 \\
2 & 4 & 100 & 90 & 2 & 46.67 & 100 & 7 & 74.54 & 95 \\
3 & 4 & 100 & 100 & 3 & 73.33 & 100 & 8 & 90.40 & 95 \\
4 & 4 & 100 & 95 & 3 & 66.67 & 100 & 8 & 82.28 & 100 \\
5 & 4 & 100 & 100 & 3 & 75 & 100 & 7 & 82.28 & 90 \\
6 & 3 & 100 & 98.33 & 3 & 100 & 98.33 & 7 & 84.41 & 98.33 \\
7 & 8 & 98.95 & 100 & 3 & 60 & 100 & 8 & 85.60 & 86.67 \\
8 & 4 & 100 & 98.33 & 2 & 40 & 93.33 & 7 & 88 & 100 \\
9 & 5 & 84.85 & 98.33 & 2 & 50 & 100 & 6 & 76.62 & 100 \\
10 & 4 & 100 & 98.33 & 3 & 73.33 & 98.33 & 7 & 83.04 & 88.33 \\
average & 4.30 & 98.38 & 95.67 & 2.70 & 64.50 & 98.83 & 7.30 & 83.28 & 95.33 \\
\hline
\end{tabular}
of calculation, $\mathrm{CBCI}$ tends to select a greater number of cheaper components while CEIM prefers a smaller number of expensive ones, but neither of those two traditionally calculated importance measures managed to give better results than our newly proposed approach applied in GLPK and GreedyPlus.

Also, it should be noted that it is possible to achieve the same system reliability improvement with the same amount of budget but with aselection of a different number of critical components. If so, all outputs of such kind are actually multiple solutions and have equal quality, but it simply looks wiser to choose a solution with fewer critical components and less time needed for their prevention. 
Table 4. Experimental results given as average values of results obtained on ten instances

\begin{tabular}{|c|c|c|c|c|c|c|c|c|c|c|c|c|c|}
\hline & & \multicolumn{3}{|c|}{$\mathrm{CBCI}$} & \multicolumn{3}{|c|}{ CEIM } & \multicolumn{3}{|c|}{ GLPK } & \multicolumn{3}{|c|}{ GreedyPlus } \\
\hline & & ABS & ANC & ARI & ABS & ANC & ARI & ABS & ANC & ARI & ABS & ANC & ARI \\
\hline \multirow{4}{*}{ 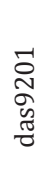 } & $B=26$ & 23.4 & 4.4 & 18.79 & 23.9 & 1.1 & 14.33 & 24.8 & 2.9 & 30.73 & 24.5 & 2.8 & 30.65 \\
\hline & $\mathrm{B}=53$ & 49.3 & 8.7 & 27.77 & 52.2 & 2.7 & 38.63 & 52.6 & 4.8 & 51.89 & 51.5 & 4.6 & 51.69 \\
\hline & $B=106$ & 102.8 & 16 & 44.89 & 104.5 & 6 & 75.72 & 104.7 & 7.4 & 82.41 & 104.2 & 7.1 & 82.33 \\
\hline & $B=160$ & 157.2 & 22.5 & 52.95 & 159.1 & 8.5 & 92.20 & 154.4 & 8.9 & 96.64 & 146.1 & 8.6 & 96.64 \\
\hline \multirow{4}{*}{ 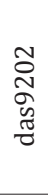 } & $B=10$ & 6.1 & 1.1 & 6.02 & 7.8 & 1 & 14.16 & 7.8 & 1 & 14.16 & 7.6 & 1 & 14.16 \\
\hline & $\mathrm{B}=21$ & 18.1 & 3 & 9.65 & 20.5 & 1.7 & 44.14 & 20 & 2 & 46.09 & 19.9 & 1.8 & 46.03 \\
\hline & $B=42$ & 38.2 & 5.8 & 12.31 & 41.3 & 2.6 & 87.29 & 41.3 & 2.8 & 87.61 & 41.3 & 2.7 & 87.60 \\
\hline & $B=64$ & 59.7 & 8.2 & 16.69 & 62.6 & 3.6 & 92.84 & 62.8 & 4.1 & 96.15 & 62.6 & 4 & 96.08 \\
\hline \multirow{4}{*}{ 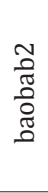 } & $B=7$ & 5.3 & 1 & 13.66 & 5.8 & 1 & 14.82 & 5.8 & 1 & 14.82 & 5.5 & 1 & 14.82 \\
\hline & $\mathrm{B}=14$ & 12 & 2 & 28.07 & 12.4 & 1.1 & 22.01 & 12.5 & 1.9 & 29.09 & 12.2 & 1.7 & 27.18 \\
\hline & $B=28$ & 26.3 & 4.1 & 43.59 & 26.6 & 1.7 & 32.83 & 27 & 3.3 & 51.64 & 26.7 & 2.8 & 50.75 \\
\hline & $\mathrm{B}=42$ & 38.8 & 5.6 & 56.45 & 40.7 & 2.3 & 45.70 & 40.9 & 4.2 & 65.86 & 40.6 & 4.1 & 65.26 \\
\hline \multirow{4}{*}{$\begin{array}{l}n \\
\frac{0}{\pi} \\
0 \\
0 \\
0 \\
0\end{array}$} & $B=17$ & 15.8 & 3 & 13.81 & 15.1 & 1.1 & 16.76 & 15.1 & 2 & 23.95 & 15 & 1.5 & 20.85 \\
\hline & $B=35$ & 31.7 & 5.4 & 25.68 & 34.7 & 2 & 25.83 & 34.3 & 3.6 & 40.62 & 33.7 & 2.5 & 35.17 \\
\hline & $\mathrm{B}=70$ & 66.3 & 10.2 & 37.24 & 68.3 & 3.1 & 41.93 & 68.9 & 5.7 & 62.48 & 68.7 & 4.3 & 57.67 \\
\hline & $B=105$ & 101.4 & 14.3 & 46.07 & 103.3 & 4.4 & 55.32 & 103.6 & 6.9 & 79.09 & 103.5 & 6.3 & 76.81 \\
\hline
\end{tabular}

Comparing GLPK outputs with the outputs of GreedyPlus, it can be observed that the improved greedy algorithm reached an average reliability improvement obtained by the exact algorithm only in three cases (das9201 with $\mathrm{B}=160$, das 9202 with $\mathrm{B}=10$ and baobab2 with $\mathrm{B}=7$ ), while all other results are very close to optimal. These three cases achieved smaller ABS value due to the way in which the improved greedy algorithm treats multiple solutions - it always picks a cheaper one, while GLPK just takes care about the goal function i.e. the overall system improvement.

\section{Conclusion}

The problem of determining the set of the most critical system components in case of a limited budget has been solved by a new approach which formulates a problem as a Budgeted Maximum Cover- age Problem. The approach is successfully tested and verified by a series of experiments over benchmark fault trees. It is concluded that in cases where MCSs are pre-known, it is more convenient to apply this new approach rather than importance measures as CBCI and CEIM.

The proposed approach could be limited by the impossibility of obtaining exact solutions in a reasonable time for the problems of large dimensions. Therefore, in a further work the presented improved greedy algorithm could be incorporated into specially designed heuristics, possibly based on Variable neighborhood search (VNS).

\section{References}

1. Armstrong M. Joint reliability importance of elements. IEEE Transactions on Reliability 1995; 44(3): 408-412, https://doi. org/10.1109/24.406574.

2. Birnbaum Z. On the importance of different components in a multicomponent system. In P. Krishnaiah (Ed.), Multivariate Analysus-II. New York: Academic Press 1969.

3. Bar-Yam Y. Dynamics of complex systems (Vol. 213). Reading, MA: Addison-Wesley 1997.

4. Borgonovo E, Apostolakis G. A new importance measure for risk-informed decision making. Reliability Engineering and System Safety 2001; 72: 193-212, https://doi.org/10.1016/S0951-8320(00)00108-3.

5. Caskurlu B, Mkrtchyan V, Perekh O, Subramani K. On Pratial Vertex Cover and Budgeted Maximum Coverage Problems in Bipartite Graphs. Theoretical Computer Science: 8th IFIP TC 1/WG 2.2 International Conference, TCS 2014, Rome, Italy: Springer 2014 ; $13-25$.

6. Curtis DE, Pemmaraju SV, Polgreen P. Budgeted Maximum Coverage with Overlapping Costs: Monitoring the Emerging Infections Network. 2010 Proceedings of the Twelfth Workshop on Algorithm Engineering and Experiments (ALENEX). Society for Industrial and Applied Mathematics 2010.

7. Der Kiureghian A, Song J. Multi-scale reliability analysis and updating of complex systems by use of linear programming. Reliability Engineering and System Safety 2008; 93(2): 288-297, https://doi.org/10.1016/j.ress.2006.10.022.

8. Du D, Ko K, Hu X. Design and analysis of appromaxition algorithms. Springer Optimization and Its Applications 2012, https://doi. org/10.1007/978-1-4614-1701-9.

9. Ericson II C A. Hazard Analysis technique for System Safety. New Jersey: John Wiley \& Sons 2015.

10. Espitrity J, Coit D, Prakash U. Component criticalty importance measures for the power industry. Electric Power Systems Research 2007; 407-420, https://doi.org/10.1016/j.epsr.2006.04.003.

11. GLPK (GNU Linear Programming Kit) From: www.gnu.org/software/glpk. 
12. Gupta S, Bachttacharya J, Barabady J, Kumar U. Cost-effective importance measure: A new approach for resource prioritization in a production plant. International Journal of Quality \& Realibility Management 2013; 30 (4): 379-386, https://doi.org/10.1108/02656711311308376.

13. Khuller S, Moss A, Naor J. The budgeted maximum coverage problem. Information Processing Letters 1999; 70 (1): 39-45, https://doi. org/10.1016/S0020-0190(99)00031-9.

14. Kuo W, Zhu X. Importance measures in reliability, risk and optimization. Chichester: John Whiley \& Sons 2012, https://doi. org/10.1002/9781118314593.

15. Ladyman J, Lambert J, Wiesner K. What is a complex system? European Journal for Philosophy of Science 2013; 3(1): 33-67, https://doi. org/10.1007/s13194-012-0056-8.

17. Li Y F, Mi J, Huang H Z, Zhu S P, Xiao N. Fault tree analysis of train rear-end collision accident considering common cause failure. Eksploatacja i Niezawodnosc - Maintenance and Reliability 2013; 15 (4): 403-408.

18. Rauzy A. A Benchmark of Boolean Formulae. From http://iml.univmrs.fr/ arauzy/aralia/ benchmark.htm.

19. Revelle C S. A bibliography for some fundamental problem categories in discrete location science. European Journal of Operational Research 2008; 184 (3): 817-848, https://doi.org/10.1016/j.ejor.2006.12.044.

20. Van der Borst M, Schoonakker H. An overview of PSA importance measures. Reliability Engineering and System Safety 2001; 72 (3): $241-$ 245, https://doi.org/10.1016/S0951-8320(01)00007-2.

21. van Heuven van Staereling I, de Keijzer B, Schafer G. The Ground-Set-Cost Budgeted Maximum Coverage Problem. 41st International Symposium on Mathematical Foundations of Computer Science (MFCS 2016). Dagstuhl Research Online Publication Server, 2016

22. Vaurio J. Ideas and developments in importance measures and fault-tree techiques for reliability and risk analysis. Reliability Engineering and System Safety 2010; 95: 99-107, https://doi.org/10.1016/j.ress.2009.08.006.

23. Vesely W, Davis T, Denning R, Saltos N. Measures of risk importance and their applications. Columbus: Battelle Columbus Labs, OH (USA), 1983, https://doi.org/10.2172/5786790.

24. Wu S. Joint importance of multistate system. Computers \& Industrial Engineering 2005; 49: 63-67, https://doi.org/10.1016/j. cie.2005.02.001.

25. Wu S, Coolen F. A cost-based importance measure for system components: An extension of the Birnbaum importance. European Journal of Operational Research 2013; 189-195, https://doi.org/10.1016/j.ejor.2012.09.034.

26. Zafiropoulos E P, Dialynas N E. Methodology for the optimal component selection of electronic devices under reliability and cost constraints. Quality and Reliability Engineering International 2007; 23 (8): 885-897, https://doi.org/10.1002/qre.850.

27. Zaitseva E, Levashenko V, Kostolny J. Application of logical differential calculus and binary decision diagram in importance analysis. Eksploatacja i Niezawodnosc - Maintenance and Reliability 2015; 17 (3): 379-388, https://doi.org/10.17531/ein.2015.3.8.

28. Zio E. Risk importance measures. In H. Pham (Ed.), Safety and risk modeling and its applications. London: Springer 2011; 151-196, https:// doi.org/10.1007/978-0-85729-470-8_6.

29. Zio E, Podofilini L. Accouniting for components interactions in the differential importance measure. Reliability Engineering and System Safety 2006; 91: 1163-1174, https://doi.org/10.1016/j.ress.2005.11.044.

30. Zio E, Podofilini L. The use of importance measures for the optimization of multi-state systems. Eksploatacja i Niezawodnosc - Maintenance and Reliability 2006; 2: 33-36.

Petar PAVLOVIĆ

Higher medical and business-technological school of applied studies in Šabac Hajduk Veljkova 10, 15000 Šabac, Serbia

Dragana MAKAJIĆ-NIKOLIĆ

University of Belgrade

Faculty of Organizational Sciences

Jove Ilića 154, 11000 Belgrade, Serbia

\section{Mirko VUJOŠEVIĆ}

University of Belgrade

Faculty of Organizational Sciences

Jove Ilića 154, 11000 Belgrade, Serbia

E-mails: petar.pavlovic@vtssa.edu.rs,makajic-nikolic.dragana@fon.bg.ac.rs, vujosevic.mirko@fon.bg.ac.rs 